\title{
Academic Libraries in an Interlibrary Loan Network
}

This paper presents the results of a survey of the users of the Florida Library Information Network (FLIN), Florida's statewide multitype interlibrary loan network. Responses to the survey provide a profile of the various types of libraries that participate in FLIN. The paper centers upon the role of academic libraries, the heaviest users of ILL in the state. Interlibrary loan staffing, request fulfillment, OCLC utilization, network performance, and other factors are discussed. Examination of these aspects of interlibrary loan provides the basis for evaluation of the critical role of academic libraries in a statewide interlibrary loan network.

\section{INTRODUCTION}

The State Library of Florida recently undertook a project with the University of Central Florida to examine interlibrary loan (ILL) among participants in the Florida Library Information Network (FLIN). The purpose of the Florida Interlibrary Loan Improvement Project (FILIP) was to examine and analyze the ILL patterns and problems in FLIN and to make recommendations for improvements. In order to conduct this examination, it was necessary to obtain a great deal of information about the nature of current statewide ILL activity. A survey was selected as the most appropriate vehicle to gather this information.

\section{BACKGROUND}

The Florida Library Information Network is a centralized multitype ILL network that serves approximately 530 academic, public, school, and special libraries in Florida. FLIN is a centralized network, begun in 1968 and headed by the State Library of

Laurie S. Linsley is coordinator, Interlibrary Loan Service, University of Central Florida. Linsley served as project director of the Florida Interlibrary Loan Improvement Project. FILIP was funded by a grant from the Library Services and Construction Act, and administered through the Division of Library Services, Department of State, State of Florida.
Florida, with the four public libraries in Jacksonville, Miami, Orlando, and Tampa serving as resource centers. The backup academic resource libraries are the nine state university system libraries and one independent academic library. The network was recently restructured, and these changes will be described later.

The description of the network outlined in this paper represents the structure at the time the study was conducted. The state library is the bibliographic center of the network and handles more than 70,000 requests annually. All network users except the fourteen resource libraries send their requests directly to the state library for processing. Requests are filled from the state library collection first. The remaining requests are then sent unverified via closed-circuit teletype to each of the four public libraries, which serve as resource centers for the network. Unfilled requests of a research nature are then verified and forwarded in turn to each of the ten academic libraries, following prescribed protocols.

More than half of the libraries in Florida have book collections of fewer than 20,000 volumes. Many of these libraries have extremely limited verification tools. Network users are encouraged to provide basic verification whenever possible, but this is not a requirement. The state library makes no attempt to verify requests sent to the public library resource centers. Requests not sup- 
plied by one of these libraries are then verified before being referred to one of the ten academic libraries or out of state. The public and academic resource libraries do not have verification responsibility. These libraries are required only to supply the material if possible.

\section{Previous Studies}

While numerous studies of various aspects of ILL have been conducted, there are no reports of interlibrary loan surveys that exactly parallel this study. There are a variety of reports of statewide ILL studies and networking activities. ${ }^{1} \mathrm{~A}$ dissertation concerning ILL among Tennessee libraries is also noteworthy. ${ }^{2}$ In this dissertation, Dianna Lynne Smith examined ILL patterns among Tennessee's academic, public, and special libraries. Her study assessed the volume and characteristics of the ILL requests initiated and received by these libraries in Tennessee. Stevens and Smith summarized the Smith dissertation and reported on the volume of ILL by type of library, characteristics of materials requested, and success rate. ${ }^{3}$

\section{ILL SURVEY}

Each of the FLIN interlibrary loan libraries was surveyed regarding its ILL activity, and a total of 372 responded. Seventy percent of the libraries responded, a high response rate for a detailed survey of this nature. Responses were received from fortyfour of the college and university libraries, with a 73 percent response rate. While these academic libraries collectively represent only 12 percent of the respondents, they lead the other libraries in book collection size, ILL staffing, utilization of ILL tools, and annual mean number of ILL requests borrowed and lent. It is the purpose of this paper to examine the unique role of these academic libraries in Florida's interlibrary loan network.

All responses were categorized according to one of these nine types of libraries: college or university; community or junior college; corporate; government or other nonprofit; military base; public; school (K-12); state institution (correctional or state hospital); other (special libraries such as art, hospital, museum, and various types of nonprofit libraries).

The libraries were polled about such items as book collection size, interlibrary loan staffing, volume of ILL, OCLC utilization, verification tools, and FLIN performance. (The full final report, which includes a copy of the survey instrument and raw scores, is available through ERIC. $)^{4}$ In the tables, $n$ signifies the number of libraries that responded to a particular question. For example, " $n=341$ " means that 341 libraries responded to that particular question. When a zero response was received, “-” is recorded instead of a percent. A zero percent (" $0 \%$ ") means that the raw score was rounded to zero percent. The figures generally do not total 100 percent because of rounding.

\section{Book Collection Size}

Responses to the first few questions of the survey provide a basic profile of the respondents. Most of the libraries (87 percent) have book collections (excluding periodicals) of under 100,000 volumes. College and university library book collections are the largest: more than half of the college and university libraries that responded to this question have book collections of more than 100,000 volumes. As can be seen in table 1, college and university library book collections are also the most evenly distributed, with the greatest percentage falling in the 100,000199,999-volume range. Only two other types of libraries report having book collections in the $500,000+-$ volume range, and in both types the incidence of this size collection is much lower than in college and university libraries.

\section{ILL Staffing PATterns}

Staffing patterns vary widely among the libraries. Generally speaking, the larger the library, the greater the number of hours and personnel devoted to ILL activities. The amount of staff time devoted to ILL activities is far greater in college and university libraries than in any other type of library. The next closest type of library in terms of time spent on ILL is the public library, which spends less than one-third as much staff time on ILL activities. In college and university libraries, librarians are devoting about half as much time to ILL as paraprofessionals. College and university libraries are the only type of library that reports a total of the equivalent of more than one full-time staff member 
TABLE 1

Size of Book Collections of Respondents BY LIBRARY TYPE $(n=370)$

\begin{tabular}{|c|c|c|c|c|c|c|c|c|c|c|}
\hline Book Volumes & $\begin{array}{l}\text { Coll/ } \\
\text { Univ }\end{array}$ & $\begin{array}{c}\text { Comm/lJ } \\
\text { Coll }\end{array}$ & Corp & Govt & Mil & Public & School & $\begin{array}{l}\text { State } \\
\text { Inst }\end{array}$ & Other & Total \\
\hline $\begin{array}{l}\text { (Total Cases) } \\
\text { Less than } \\
20,000\end{array}$ & $\begin{array}{l}(44) \\
12 \%\end{array}$ & $\begin{array}{l}(38) \\
16 \%\end{array}$ & $\begin{array}{l}(12) \\
83 \%\end{array}$ & $\begin{array}{l}(43) \\
86 \%\end{array}$ & $\begin{array}{l}(6) \\
17 \%\end{array}$ & $\begin{array}{l}(110) \\
32 \%\end{array}$ & $\begin{array}{l}(40) \\
73 \%\end{array}$ & $\begin{array}{l}(32) \\
97 \%\end{array}$ & $\begin{array}{l}(47) \\
87 \%\end{array}$ & $\begin{array}{l}(372) \\
52 \%\end{array}$ \\
\hline $\begin{array}{l}20,000- \\
49,999\end{array}$ & 16 & 45 & 17 & 14 & 83 & 32 & 25 & - & 9 & 23 \\
\hline $\begin{array}{l}50,000- \\
99,999\end{array}$ & 16 & 29 & - & - & - & 21 & 2 & 3 & - & 12 \\
\hline $\begin{array}{l}100,000- \\
199,999\end{array}$ & 28 & 10 & - & - & - & 8 & - & - & 2 & 7 \\
\hline $\begin{array}{l}200,000- \\
499,999\end{array}$ & 19 & - & - & - & - & 3 & - & - & 2 & 3 \\
\hline $500,000+$ & 9 & - & - & - & - & 4 & - & - & 0 & 2 \\
\hline
\end{tabular}

devoted to ILL. (See table 2.)

\section{ILL BORROWING}

The survey reveals that by far the greatest level of borrowing is done by the college and university libraries and the public libraries. The form of material being requested (photocopied articles and books) is generally what would be expected. College and university libraries and some of the special libraries (corporate and government) borrow more photocopied articles than books.

Community colleges, public libraries, and school libraries, and some of the special libraries (military, state institution, and other) borrow more books than articles: the total mean number of books borrowed is almost twice that of photocopies. The fill rate for both books and photocopies for these li- braries is more than 80 percent.

The fill rate for books requested by college and university libraries is relatively low, only 74 percent. This could be explained by the tight deadlines imposed by course requirements in colleges and universities. Public library patrons are generally willing to wait longer for materials than are college and university faculty and students. (See table 3.)

The survey reveals some particularly interesting information about ILL borrowing from the academic libraries. Almost half (44 percent) of all the libraries report that the majority of requested materials are received from college or university libraries. This is understandable, since these libraries have the largest book collections in Florida. They also participate heavily in OCLC, so that knowledge of their holdings is more easily as-

TABLE 2

INTERLIBRARY LOAN STAFFing PATtERnS BY LIBRARY TYPE

\begin{tabular}{|c|c|c|c|c|c|c|c|c|c|c|}
\hline Personnel/Type & $\begin{array}{l}\text { Coll// } \\
\text { Univiv }\end{array}$ & $\begin{array}{l}\text { Comm/ } \\
\text { Jr Coll }\end{array}$ & Corp & Govt & Mil & Public & School & $\begin{array}{c}\text { State } \\
\text { Inst }\end{array}$ & Other & $\begin{array}{l}\text { Total/ } \\
\text { Mean }\end{array}$ \\
\hline $\begin{array}{l}\text { (Total Cases) } \\
\text { Mean \# of } \\
\text { Hrs./Wk Spent }\end{array}$ & $\begin{array}{c}(44) \\
\text { Hrs/Wk }\end{array}$ & $\begin{array}{c}(38) \\
\text { Hrs/Wk }\end{array}$ & $\begin{array}{c}(12) \\
\text { Hrs/Wk }\end{array}$ & $\begin{array}{c}(43) \\
\text { Hrs/Wk }\end{array}$ & $\begin{array}{c}(6) \\
\text { Hrs/Wl }\end{array}$ & $\begin{array}{c}(110) \\
\text { Hrs/Wk }\end{array}$ & $\begin{array}{c}(40) \\
\text { Hrs/Wk }\end{array}$ & $\begin{array}{c}(32) \\
\text { Hrs/Wk }\end{array}$ & $\begin{array}{c}(47) \\
\text { Hrs/Wk }\end{array}$ & $\begin{array}{c}(372) \\
\text { Hrs/Wk }\end{array}$ \\
\hline $\begin{array}{l}\text { on ILL } \\
\text { By Librarian } \\
(n=315)\end{array}$ & 9.2 & 2.2 & 3.3 & 5 & .4 & .7 & 1.1 & 2.6 & 6.4 & 4.3 \\
\hline $\begin{array}{l}\text { By Paraprof. } \\
(n=275)\end{array}$ & 18.7 & 1.4 & 6.0 & 3.3 & 1.8 & 5.0 & .0 & 2.1 & 1.4 & 5.0 \\
\hline $\begin{array}{l}\text { By Clerk } \\
(n=279)\end{array}$ & 10.8 & 1.4 & .0 & 1.9 & .3 & 4.9 & .2 & 4.4 & 4.6 & 4.2 \\
\hline $\begin{array}{l}\text { By Other Assts. } \\
(n=272)\end{array}$ & 13.5 & .6 & .0 & .8 & .0 & 1.0 & .0 & 2.0 & .3 & 2.6 \\
\hline Total Hrs/Wk & 52.2 & 5.6 & 9.3 & 9.5 & 2.5 & 15.6 & 1.3 & 11.1 & 12.7 & \\
\hline
\end{tabular}


TABLE 3

Interlibrary Loan Borrowing Statistics/Most Recent Reporting Year BY LIBRARY TYPE

\begin{tabular}{|c|c|c|c|c|c|c|c|c|c|c|}
\hline & $\begin{array}{l}\text { Coll/ } \\
\text { Univ }\end{array}$ & $\begin{array}{l}\text { Comm/ } / \\
\text { Jr Coll }\end{array}$ & Corp & Govt & Mil & Public & School & $\begin{array}{l}\text { State } \\
\text { Inst }\end{array}$ & Other & $\begin{array}{l}\text { Total/ } \\
\text { Mean }\end{array}$ \\
\hline (Total Cases) & (44) & (38) & (12) & (43) & (6) & (110) & $(40)$ & (32) & (47) & (372) \\
\hline $\begin{array}{l}\text { Mean \# of } \\
\text { photocopied } \\
\text { articles } \\
\text { borrowed } \\
(n=294)\end{array}$ & 409 & 45 & 223 & 185 & 3 & 14 & 4 & 6 & 131 & 103 \\
\hline $\begin{array}{l}\text { Fill rate- } \\
\text { photocopied } \\
\text { articles } \\
(n=199)\end{array}$ & $85 \%$ & $83 \%$ & $94 \%$ & $88 \%$ & $50 \%$ & $84 \%$ & $82 \%$ & $82 \%$ & $97 \%$ & $86 \%$ \\
\hline $\begin{array}{l}\text { Mean \# of } \\
\text { bks borrowed } \\
(n=303)\end{array}$ & 332 & 48 & 19 & 40 & 49 & 378 & 24 & 131 & 225 & 205 \\
\hline $\begin{array}{l}\text { Fill rate- } \\
\text { bks }(n=243)\end{array}$ & $74 \%$ & $86 \%$ & $91 \%$ & $84 \%$ & $97 \%$ & $78 \%$ & $82 \%$ & $76 \%$ & 91 & $82 \%$ \\
\hline
\end{tabular}

TABLE 4

INTERLIBRARY LOAN BORROWING BY TYPE OF REQUESTING LIBRARY

\begin{tabular}{lcccccccccc}
\hline \hline Supplying Libraries & $\begin{array}{c}\text { Coll/ } \\
\text { Univ }\end{array}$ & $\begin{array}{c}\text { Comm/ } \\
\text { Jr Coll }\end{array}$ & Corp & Govt & Mil & Public & School & $\begin{array}{c}\text { State } \\
\text { Inst }\end{array}$ & Other & Total \\
\hline Total Cases) & $(44)$ & $(38)$ & $(12)$ & $(43)$ & $(6)$ & $(110)$ & $(40)$ & $(32)$ & $(47)$ & $(372)$ \\
Coll/Univ & $100 \%$ & $76 \%$ & $67 \%$ & $43 \%$ & $25 \%$ & $17 \%$ & $43 \%$ & $7 \%$ & $46 \%$ & $44 \%$ \\
Comm/Jr Coll & - & 5 & - & - & - & 1 & - & - & - & 1 \\
Corp & - & - & 17 & - & - & - & - & - & - & 1 \\
Govt & - & 8 & 8 & 40 & 25 & 8 & 7 & 14 & 3 & 11 \\
Mil & - & - & - & - & 25 & - & - & - & - & 0 \\
Pub & - & 3 & - & 3 & 25 & 55 & 33 & 50 & 9 & 26 \\
Sch & - & - & - & - & - & - & 13 & - & - & 1 \\
State Inst. & - & - & - & - & - & - & - & 4 & - & 0 \\
Other* & - & 8 & 8 & 14 & - & 20 & 3 & 25 & 43 & 16 \\
\hline
\end{tabular}

-The State Library of Florida was specified in most cases.

certained. Figures reported in table 4 also substantiate the common belief that libraries tend to borrow from like types of libraries.

\section{ILL LENDING}

As anticipated, the survey reveals that the greatest level of lending is achieved by college and university libraries and the public libraries. The form of material being lent (photocopied articles versus books) is quite evenly balanced in college and university libraries. Only two types of libraries, corporate and state institution, lend more photocopies than books, but both of these types of libraries report very low means. The mean fill rates for lending are somewhat lower than those for borrowing, although the lending fill rate for books by the academic libraries is higher than borrowing (79 percent versus 74 percent). (See table 5.)

\section{Total ILL Volume}

We have been discussing ILL borrowing and lending in terms of means. This does not show the entire picture, because the fortyfour college and university libraries represent only 12 percent of the respondents. In terms of total volume, what types of libraries lead in interlibrary loan borrowing and lending? The 110 public libraries borrow and lend more items than any other type of library. The college and university libraries follow closely in second place. Together, the college and university libraries and public libraries borrow 66 percent of the items and lend 88 percent of the items. The volume of lending is almost perfectly balanced between these two net lenders. The ratio of borrowing to lending in Florida's college and university libraries $(1: 1.6)$ is comparable to that re- 
ported by the Association of College and Research Libraries (1:1.5). ${ }^{5}$ (See table 6.)

\section{OCLC ILL SUBSYSTEM}

The libraries were queried regarding the use of the OCLC Interlibrary Loan Subsystem. For both borrowing and lending, more than half of the total subsystem usage is accounted for by college and university libraries. A few more libraries are filling requests through the subsystem than are using it for initiating requests (see table 7). Note that percentages are based on number of responses to that particular question.

TABLE 5

Interlibrary Loan Lending StatisticsMost Recent Reporting Year

\begin{tabular}{|c|c|c|c|c|c|c|c|c|c|c|}
\hline & $\begin{array}{l}\text { Coll// } \\
\text { Univ }\end{array}$ & $\begin{array}{l}\text { Comm/ } \\
\text { Jr Coll }\end{array}$ & Corp & Govt & Mil & Public & School & $\begin{array}{c}\text { State } \\
\text { Inst }\end{array}$ & Other & $\begin{array}{l}\text { Total/ } \\
\text { Mean }\end{array}$ \\
\hline (Total Cases) & (44) & (38) & (12) & (43) & (6) & (110) & (40) & (32) & (47) & (372) \\
\hline $\begin{array}{l}\text { Mean no. of } \\
\text { photocopied } \\
\text { articles } \\
\text { lent }(n=168)\end{array}$ & $637^{\prime}$ & 8 & 7 & 101 & 2 & 20 & 7 & 5 & $87^{\prime}$ & 164 \\
\hline $\begin{array}{l}\text { Fill rate - } \\
\text { photocopied } \\
\text { articles } \\
\text { lent }(n=128)\end{array}$ & $74 \%$ & $73 \%$ & $85 \%$ & $96 \%$ & $89 \%$ & $78 \%$ & $80 \%$ & $100 \%$ & $78 \%$ & $80 \%$ \\
\hline $\begin{array}{l}\text { Mean no. of } \\
\text { bks lent } \\
(n=146)\end{array}$ & 639 & 33 & 3 & 112 & 11 & 1136 & 9 & 0 & 203 & 460 \\
\hline $\begin{array}{l}\text { Fill rate- } \\
\text { bks lent } \\
(n=121)\end{array}$ & $79 \%$ & $84 \%$ & $88 \%$ & $75 \%$ & $54 \%$ & $77 \%$ & $87 \%$ & - & $68 \%$ & $78 \%$ \\
\hline
\end{tabular}

TABLE 6

Interlibrary Loan Volume/Most Recent Reporting Year by Libraky Type

\begin{tabular}{lcccccccccr}
\hline \hline & $\begin{array}{l}\text { Coll/ } \\
\text { Univ }\end{array}$ & $\begin{array}{c}\text { Comm/ } \\
\text { Jr Coll }\end{array}$ & Corp & Govt & Mil & Public & School & $\begin{array}{c}\text { State } \\
\text { Inst }\end{array}$ & Other & Total \\
\hline Total Cases) & $(44)$ & $(38)$ & $(12)$ & $(43)$ & $(6)$ & $(110)$ & $(40)$ & $(32)$ & $(47)$ & $(372)$ \\
Items borrowed & 25,132 & 3,300 & 2,898 & 7,441 & 207 & 35,637 & 768 & 3,782 & 13,027 & 92,192 \\
Items lent & 40,184 & 887 & 74 & 4,111 & 53 & 40,356 & 150 & 31 & 5,908 & 91,754 \\
\hline
\end{tabular}

TABLE 7

USE OF OCLC ILL SUBSYSTEM BY LIBRARY TYPE

\begin{tabular}{|c|c|c|c|c|c|c|c|c|c|c|}
\hline & $\begin{array}{l}\text { Coll// } \\
\text { Univ }\end{array}$ & $\begin{array}{l}\text { Comm/ } \\
\text { Jr Coll }\end{array}$ & Corp & Govt & Mil & Public & School & $\begin{array}{l}\text { State } \\
\text { Inst }\end{array}$ & Other & $\begin{array}{l}\text { Total/ } \\
\text { Mean }\end{array}$ \\
\hline (Total Cases) & (44) & (38) & (12) & (43) & (6) & (110) & (40) & $(32)$ & $(47)$ & (372) \\
\hline $\begin{array}{l}\text { Send reqs. via } \\
\text { OCLC ILL }\end{array}$ & & $1 \%$ & $0 \%$ & $1 \%$ & : & $1 \%$ & - & . & $1 \%$ & $8 \%$ \\
\hline $\begin{array}{l}\text { Sub. }(n=341) \\
\text { Have OCLC, but } \\
\text { do not send } \\
\text { via Sub. } \\
(n=341)\end{array}$ & 3 & 2 & - & 1 & $0 \%$ & 3 & - & $0 \%$ & 2 & 11 \\
\hline $\begin{array}{l}\text { Do Not Have } \\
\text { OCLC }(n=341)\end{array}$ & 5 & 8 & 3 & 10 & 1 & 27 & $10 \%$ & 8 & 9 & 81 \\
\hline $\begin{array}{l}\text { Fill regs. via } \\
\text { OCLCILL } \\
\text { Sub. }(n=180)\end{array}$ & 9 & 2 & 1 & 2 & - & 2 & - & - & 1 & 17 \\
\hline $\begin{array}{l}\text { Have OCLC, but } \\
\text { do not fill } \\
\text { via Sub. } \\
(n=180)\end{array}$ & 3 & 5 & - & 1 & 1 & 2 & - & - & 2 & 13 \\
\hline $\begin{array}{l}\text { Do Not Have } \\
\text { OCLC }(n=180)\end{array}$ & 5 & 7 & 2 & 16 & 2 & 19 & 8 & 3 & 9 & 71 \\
\hline
\end{tabular}


Table 8 details further the use of OCLC in college and university libraries. Percentages in this table are based on responses of only this type of library and reflect the portion of libraries as a percentage of the total number of libraries (forty-four) in order to provide an even clearer picture of OCLC usage in the academic libraries. Almost a third of the academics are sending their requests through the subsystem, while a few more ( 36 percent) are filling requests through the subsystem. A relatively low percentage of academics, 11 percent, are not filling requests received through the subsystem. College and university libraries utilize the subsystem more than any other type of library which has access to it.

At the time the FILIP survey was conducted, the OCLC Interlibrary Loan Subsystem was not an integral part of the statewide interlibrary loan network. Individual libraries sent requests or responded to re-

TABLE 8

USE OF OCLC ILL SUBSYSTEMAACADEMIC LiBRARIES BY LIBRARY TYPE

\begin{tabular}{lc}
\hline & $\begin{array}{c}\text { Coll/ } \\
\text { Univ } \\
(44)\end{array}$ \\
\hline $\begin{array}{l}\text { Send reqs. via OCLC } \\
\text { ILL Sub. }(n=43)\end{array}$ & $32 \%$ \\
$\begin{array}{l}\text { Have OCLC, but do not } \\
\text { send via Sub. }(n=43)\end{array}$ & 25 \\
$\begin{array}{l}\text { Do not have OCLC }(n=43) \\
\text { Fill reqs. via OCLC }\end{array}$ & 41 \\
ILL Sub. $(n=31)$ & 36 \\
$\begin{array}{l}\text { Have OCLC, but do not } \\
\text { fill via Sub. }(n=31)\end{array}$ & 11 \\
Do not have OCLC $(n=31)$ & 23 \\
\hline
\end{tabular}

quests via the subsystem as they wished, but FLIN did not utilize the subsystem for referrals. A major recommendation that resulted from this project was a trial test of the OCLC Interlibrary Loan System in order to determine its usefulness for FLIN referrals. This will be described in the "Project Recommendations" section, below.

\section{FLORIDA COMCAT AND FULS}

A major verification tool for books is Florida COMCAT. This is a microfiche listing that contains the catalog holdings of major Florida libraries. Only 7 percent of the FLIN libraries use this valuable location and verification tool. Two-thirds of the libraries do not even own Florida COMCAT. The Florida Union List of Serials (FULS) contains serials locations for many Florida libraries. Only a third of the libraries use this tool for interlibrary loan, and almost half of the libraries report that they do not own FULS. (See table 9.)

Florida libraries are not taking full advantage of the basic verification and location tools for the state. What circumstances have led to this situation? Prior to this study, it had been assumed that the majority of FLIN users owned Florida COMCAT and used it for verification and location. However, actual usage was found to be exceedingly low. Libraries who have access to OCLC have little need for Florida COMCAT, since the same holdings information is available via OCLC.

The greatest value of Florida COMCAT is for the state's smaller libraries. This micro-

TABLE 9

INTERLIBRARY LOAN VERIFICATIONLLCATION TOOLS BY LIBRARY TYPE

\begin{tabular}{|c|c|c|c|c|c|c|c|c|c|c|}
\hline & $\begin{array}{l}\text { Coll/ } \\
\text { Univ }\end{array}$ & $\begin{array}{l}\text { Comm/ } \\
\text { Jr Coll }\end{array}$ & Corp & Govt & Mil & Public & School & $\begin{array}{l}\text { State } \\
\text { Inst }\end{array}$ & Other & Total \\
\hline (Total Cases) & (44) & (38) & (12) & (43) & (6) & (110) & $(40)$ & (32) & $(47)$ & (372) \\
\hline $\begin{array}{l}\text { Use Fla. COMCAT } \\
\text { for ILL }(n=346)\end{array}$ & $3 \%$ & $1 \%$ & $0 \%$ & (170) & (0) & $3 \%$ & (70) & (102) & $0 \%$ & $7 \%$ \\
\hline $\begin{array}{l}\text { Have Fla. COMCAT, } \\
\text { but do not use } \\
\text { for ILL }(n=346)\end{array}$ & 4 & 4 & 1 & $2 \%$ & $0 \%$ & 8 & $3 \%$ & $6 \%$ & 4 & 28 \\
\hline $\begin{array}{l}\text { Do not own Fla. } \\
\text { COMCAT }(n=346)\end{array}$ & 5 & 6 & 2 & 9 & 1 & 21 & 8 & 11 & 7 & 66 \\
\hline $\begin{array}{l}\text { Use FULS for } \\
\text { ILL }(n=347)\end{array}$ & 10 & 7 & 2 & 5 & 1 & 4 & - & - & 4 & 33 \\
\hline $\begin{array}{l}\text { Have FULS, but } \\
\text { do not use for } \\
\text { ILL }(n=347)\end{array}$ & 1 & 2 & 1 & 2 & 1 & 11 & 3 & 3 & 2 & 26 \\
\hline $\begin{array}{l}\text { Do not own FULS } \\
(n=347)\end{array}$ & 1 & 1 & 1 & 5 & 1 & 16 & 7 & 6 & 4 & 42 \\
\hline
\end{tabular}


fiche can be utilized for bibliographic verification of books by title. This simple verification step makes ILL requests channeled through the State Library of Florida much more efficacious. The state library, which serves as the bibliographic center of FLIN, can then immediately forward a request to a library that owns the book. A library that has a local cooperative agreement can use Florida COMCAT to find a nearby location as a borrowing source, and then send a request directly to a nearby library which owns it.

The FILIP survey had two questions relating to Florida COMCAT, as well as a glossary that provided a brief definition for each term used in the survey. A number of responding libraries indicated that they had never heard of Florida COMCAT before and requested information about obtaining a copy of it. The FILIP survey itself therefore served as an educational tool. The smallest libraries in Florida often do not have microfiche readers and therefore they cannot use Florida COMCAT. The groups of libraries described above comprise the Florida COMCAT nonusers.

The utilization of FULS is concerned with very different circumstances. Expressed in sheer volume, Florida COMCAT is more valuable to Florida libraries than FULS, because FLIN libraries borrow twice as many books as photocopies. Since the most current edition is on microfiche, the same restrictions apply to this tool as to Florida COMCAT.

The results of the FILIP survey indicate that Florida libraries are not taking full advantage of these excellent regional verification and location tools. Complete utilization of these basic ILL tools could have a tremendous positive impact on the future success of ILL requests for FLIN libraries.

\section{FLIN PERFORMANCE}

The Florida libraries were asked to comment on the weaknesses of the network in a narrative portion of the survey. The complaint that was recurringly voiced by all types of librarians was summed up by one public librarian: "They are so SLOW!" Librarians seemed well aware of the continually growing number of requests that the state library must process with no increase in staff. Lack of communication with the network users was also evidenced by the respon- dents' requests for regular meetings and updates on network policy. While recognizing its shortcomings, most of the librarians expressed gratitude for the existence of the ILL network. The majority of Florida librarians (67 percent) rate the overall performance of the Florida Library Information Network as excellent or good. A small percentage of librarians rate the network as adequate, fair, or poor. (See table 10.)

\section{Project Recommendations}

Major recommendations of the project were:

1. The State Library of Florida will conduct a trial test of the OCLC Interlibrary Loan Subsystem for the referral of ILL requests in the Florida Library Information Network. The state library will analyze and evaluate the results of this test.

2. The State Library of Florida will widely publicize the availability of Florida COMCAT and encourage the utilization of Florida COMCAT as a location and verification tool.

3. The State Library of Florida will phase out the TWX and teletype linkage with the FLIN resource libraries. The state library will encourage utilization of the OCLC Interlibrary Loan Subsystem for sending and receiving requests.

\section{Present Network Structure}

The State Library of Florida has made significant alterations in the Florida Library Information Network, based upon the recommendations of this FILIP study, as well as the recommendations of a study conducted by Robert S. Gorin and Ronald A. Kanen of the state library staff. ${ }^{6}$ The latter study compared the use of OCLC, TWX, the U.S. Postal Service, and closed-circuit teletype for the referral of FLIN interlibrary loan requests to the fourteen resource libraries during February and March 1981.

State library verification of requests is the major modification that has been made in the ILL network. Finding a location for most book requests ensures greater efficiency and accuracy for referral of ILL requests through the network. Additionally, greater use is being made of the ten academic resource libraries. Previously, protocol required that requests for certain types of materials not be 
TABLE 10

FLIN PERFORMANCE BY LIBRARY TyPE $(n=310)$

\begin{tabular}{lllllllllll}
\hline & $\begin{array}{l}\text { Coll/ } \\
\text { Univ }\end{array}$ & $\begin{array}{c}\text { Comm/Jr } \\
\text { Coll }\end{array}$ & Corp & Govt & Mil & Public & School & $\begin{array}{l}\text { State } \\
\text { Inst }\end{array}$ & Other & Total \\
\hline (Total Cases) & $(44)$ & $(38)$ & $(12)$ & $(43)$ & $(6)$ & $(110)$ & $(40)$ & $(32)$ & $(47)$ & $(372)$ \\
Excellent & $1.6 \%$ & $3.5 \%$ & $1.0 \%$ & $3.2 \%$ & $.3 \%$ & $12.6 \%$ & $5.8 \%$ & $3.9 \%$ & $1.0 \%$ & $32.9 \%$ \\
Good & 2.6 & 2.9 & .6 & 4.8 & .6 & 15.2 & 1.9 & 3.5 & 1.9 & 34.0 \\
Adequate & .3 & .6 & .3 & 1.0 & - & 3.2 & .3 & - & - & 5.7 \\
Fair & 1.3 & 1.9 & - & - & - & 1.6 & - & 1.3 & - & 6.1 \\
Poor & -.3 & 1.0 & .3 & - & - & - & - & .3 & .3 & 1.9 \\
Do not use & 5.5 & 1.6 & .6 & 1.6 & .6 & 1.3 & 1.9 & .3 & 5.5 & 18.9 \\
\hline
\end{tabular}

forwarded on to the academic resource libraries. With full verification, this type of request is now referred to an academic resource library which owns the title, if no public library resource center can supply it. ${ }^{7}$

Based upon statistics obtained from this study, the State Library of Florida has retained the closed-circuit teletype linkage with the four public library resource centers. This was found to be the most effective and efficient method of communication with these libraries. The OCLC Interlibrary Loan Subsystem was chosen as the most effective method for referring requests to the ten academic resource libraries, as well as to out-ofstate libraries. The TWX network has been discontinued, as it was found to be the most inefficient method for referring ILL requests. ${ }^{8}$

\section{Conclusion}

The Florida Interlibrary Loan Improvement Project, which is the first statewide in- terlibrary loan study of this depth, provides details on ILL activity among the state's academic, public, school, and special libraries. Participants in the Florida Library Information Network, Florida's centralized, multitype ILL network, were polled about such items as ILL staffing, volume, tools, and FLIN performance. While college and university libraries collectively represent only 12 percent of the respondents, it was quite apparent that these forty-four libraries play a unique network role. The academic libraries have the largest book collections and the most ILL staff; their means for borrowing and lending are higher than any other type of library; they lend almost half of the total items loaned in the state; they utilize the OCLC ILL Subsystem more than any other type of library.

Academic libraries, while relatively small in number, are vital members of Florida's interlibrary loan network.

\section{REFERENCES 5287 .}

1. Some of these are: Interlibrary Cooperation; a Wisconsin Plan. Report of the Task Force on Interlibrary Cooperation and Resource Sharing (Madison: Wisconsin Department of Public Instruction, Division of Library Services, 1976; ERIC Document Reproduction Service, ED 130 666); A Study of Interlibrary Loan Transactions in the Texas Information Exchange (Austin: Texas Information Exchange, 1976; ERIC Document Reproduction Service, ED 156 190); A Study of Organization and Governance of Alabama State Library Systems (Montgomery: Alabama Public Library Service, 1978; ERIC Document Reproduction Service, ED 163930 ).

2. Dianna Lynne Smith, "The Magnitude and Characteristics of Interlibrary Loan Involving Public, Academic, and Special Libraries in Tennessee" (Ph.D. dissertation, Univ. of Illinois, 1976).
3. Rolland E. Stevens and Dianna Lynne Smith, "Interlibrary Loan in Tennessee," Southeastern Librarian 27:175-80 (Fall 1977).

4. Laurie S. Linsley, Florida Interlibrary Loan Improvement Project. Final Report (Tallahassee: Department of State, State Library of Florida, 1980; ERIC Document Reproduction Service, ED 200209 ).

5. "ACRL Statistics Reported," College \& Research Libraries News 41:193 (July/Aug. 1980).

6. Robert S. Gorin and Ronald A. Kanen, Florida Library Information Network Project: A Comparative Study of OCLC, TWX, U.S. Mail and Closed-Circuit Teletype (Tallahassee: Department of State, State Library of Florida, 1981).

7. Gorin and Kanen, Florida Library Information Network, p.31-32.

8. Gorin and Kanen, Florida Library Information Network, p.33. 